\title{
Article \\ Investigation of health condition of small indigenous species Channa punctatus from Sherpur and Mymensingh areas
}

\author{
Gias Uddin Ahmed, Sahara Khatun and Md. Mamunur Rahman \\ Department of Aquaculture, Faculty of Fisheries, Bangladesh Agricultural University, Mymensingh, \\ Bangladesh
}

*Corresponding author: Md. Mamunur Rahman, Department of Aquaculture, Bangladesh Agricultural University, Mymensingh-2202, Bangladesh. E-mail: mamunurrahman125@gmail.com

Received: 07 September 2016/Accepted: 26 September 2016/ Published: 29 September 2016

\begin{abstract}
Investigation on the health condition of small indigenous fish, Channa punctatus was carried out through clinical and histological observation from Jailka beel of Sherpur sadar, Sherpur district and Kailla beel of Ishargonj upazila, Mymensingh district for a period of six months from October 2014 to March 2015. Water quality parameters like water temperature, $\mathrm{pH}$, dissolved oxygen, ammonia, total hardness, alkalinity and nitrate were recorded. Water temperature and total hardness were found at unfavorable level for fish in December and January. Clinical examinations of the fish were also carried out for any kind of abnormalities at monthly intervals. Clinically, it was observed that fish was affected with numerous red spots and patches in lateral and ventral regions, large deep whitish ulcers reached up to deep ulcers especially in December and January in both the beels. Samples of skin, muscle, gill, liver and kidney were collected and processed for histological observations. Major pathology in the skin and muscle were epidermis separated from dermis, presence of fungal granuloma, vacuums, hemorrhage and necrosis. Loss of primary and secondary gill lamellae, hypertrophy and primary gill lamellae separated, necrosis and hemorrhage were found in the gill. Large vacuums, necrosis and hemorrhage were observed in liver and kidney. Among the affected fish organs, skin and muscle, gills were found to be more affected than those of the internal organs like liver and kidney. Overall, under the clinical and histopathological observations the fish were found to be more affected in December and January. Whereas, in the months of February and March, the pathological condition of fish gradually healed up to normal except few vacuums and hemorrhage. Under histopathological observations, fish of Jailka beel were more affected than the fish of Kailla beel. In clinical and histopathological observation $C$. punctatus was more affected due to EUS.
\end{abstract}

Keywords: small indigenous species; Channa punctatus; clinical and histopathological observations; water quality parameters

\section{Introduction}

In Bangladesh small indigenous fish contribute significantly to overcome malnutrition in the country. This species of fish always remain available for daily consumption of all classes of people especially low-income groups, due to their low price, food taste and good flavor and high nutritional quality. Beels are very good natural habitat of large and small indigenous fishes of different food habits. The term 'beel' is used in other areas of the country to denote natural depression of smaller size and area. In Mymensingh area there are 1,809 beels covering an area of 22,889 ha. Among them 58\% are permanent and $42 \%$ are seasonal (Rahman, 1989). The small indigenous species (SIS) of Bangladesh are generally considered to be those fishes which grow to a length of about $25 \mathrm{~cm}$ or inches (Felts et al., 1996; Hossain and Afroze, 1991). These small fishes are available in smaller water bodies like drains, ditches and larger water bodies like pond, lakes, beels, haor, baor, rivers, stream, ephemeral water bodies of the inland and estuaries areas. SIS has high nutritional value in terms of protein, vitamin, and minerals and these micronutrients are not commonly available in other foods (Thilsted $e t$ 
al., 1997). These groups of fish contain large amount of calcium and also iron and zinc (Tripathi, 1997). Moreover this small indigenous fish species are maintaining a stable and static condition of our aquatic food chain thus the biodiversity of our open water ecology have in smooth form. But natural populations of this small fish is rapidly decreasing due to over exploitation, lack of scientific management, draining out of beels, natural disaster (draught and siltation) and poor environmental conditions. Because the water quality of beels, baors, rivers and canals are decreasing day by day. As a result, fish species that breed and reared in natural waters are reducing quickly. Thus fishes of open water bodies are facing continuous stress, which leads to infection and disease. Health condition and disease has become a major problem in fish production both in culture system and wild condition in Bangladesh (Rahman and Chowdhury, 1996). Common diseases of open water fishes of Bangladesh are tail and fin rot, bacterial gill rot, dropsy, various types of fungal disease, protozoan disease, parasitic disease, nutritional disease, tumors (Chowdhury, 1993). With the outbreak of epizootic ulcerative syndrome (EUS) in 1988, Channa spp., Puntius spp., Anabas spp. and other indigenous species of fish are seriously affected (Barua et al., 1989). The water quality parameters such as temperature, dissolved oxygen, $\mathrm{pH}$, total alkalinity, total hardness and ammonia could be associated with outbreaks of disease (Subasinghe, 1995). It indicated the possible relationship between the occurrence of disease and the environmental parameters. Histopathological technique is one of the most important procedures for disease diagnosis in fish. It has been successfully used throughout the world. It was thus necessary to investigate health condition of fish through some suitable techniques. Considering the above facts the present study has been undertaken with the following objectives: to investigate water quality parameters of Jailka beel and Kailla beel and also observe the health status of $C$. punctatus of the two beels in relation to different months.

\section{Materials and Methods}

In the present investigation two beels were selected; they were Jailka beel and Kailla beel. The study was conducted for a period of six months from October 2014 to March 2015 to find out the health condition of a small indigenous species, $C$. punctatus. Water samples were collected from the Kailla beel and Jailka beel once in a month between 08.00 to 08.30 am and water quality parameters test on spot. Water quality parameters like temperature, $\mathrm{pH}$, dissolved oxygen, ammonia, total hardness, alkalinity and nitrite were measured by using respective test kits. Fish samples from both regions were collected from nearby local fisherman. A total of 8 live fishes were collected during each sampling area. The sampled fishes were clinically examined by naked eye and magnifying glass to record any external signs, injury and other abnormalities. Organs like skin and muscle, gill, liver and kidney were collected with the help of a sharp scalpel and forceps and fixed in $10 \%$ neutral buffered formalin for histopathological study. After 8 hours of fixation, the samples were trimmed in order to obtain a standard size of $1 \mathrm{~cm}^{3}$ (maximum) and placed in automatic tissue processor for dehydration, clearing and infiltration. The samples were then embedded, sectioned (5 $\mu \mathrm{m}$ thickness) and stained with Haematoxylin and Eosin. Then the sections were mounted with canada balsam and covered by cover slips and examined under a compound microscope. Photomicrograph of the stained sections was obtained by using a photomicroscope. Record of structural variations and pathologies were done from the slides and photomicrographs (Ahmed et al., 2012).

\section{Results and Discussion}

\subsection{Water quality parameters}

Water quality of the Jailka beel and Kailla beel was studied from October 2014 to March 2015. Data regarding water temperature, $\mathrm{pH}$, dissolved oxygen (DO), ammonia, total hardness, alkalinity and nitrite were analyzed and presented in Table 1.

Water quality parameters are important considerations of fish health management. In the present study, the highest water temperature $\left(28^{0} \mathrm{C}\right)$ was recorded in October (2014) in both the beels. On the other hand, the lowest value of temperature was recorded $21.50{ }^{\circ} \mathrm{C}-22{ }^{\circ} \mathrm{C}$ in January and December in both the beels. Mondal (2012) recorded water temperature were ranged from 17 to $31^{\circ} \mathrm{C}$ in BAU fish farm. According to Akter et al. (2009) there was a decreased value of temperature during winter season in Kailla beel of Mymensingh. In the present experiment, the $\mathrm{pH}$ values were ranged from 6.8 to 7.5 in Jailka beel and 6.6 to 7.5 in Kailla beel. Mondal (2012) recorded that $\mathrm{pH}$ values were ranged from 7.0 to 7.7 in BAU fish farm and Swopon fish farm throughout the experimental period. Most natural water has $\mathrm{pH}$ values of 6.5 to 9 (Alim, 2005). According to Swingle (1967) $\mathrm{pH}$ value of 6.5 to 9 is suitable for fish culture. In the present experiment, the values of dissolved oxygen were ranged from 4.0 to $5.0 \mathrm{mg} / \mathrm{l}$ in Jailka beel and 4.0 to $4.5 \mathrm{mg} / \mathrm{l}$ in Kailla beel. Ahmed et al. (2009) reported that dissolved oxygen ranged from 5.5 to 3.0 in four beels of Mymensingh. 
Table 1. Monthly variations of water quality parameters of the Jailka and kailla beels.

\begin{tabular}{|c|c|c|c|c|c|c|c|}
\hline Parameters & Beels & Oct & Nov & Dec & Jan & Feb & Mar \\
\hline \multirow[t]{2}{*}{ Temperature $\left({ }^{0} \mathrm{C}\right)$} & Jailka beel & 28.3 & 27.5 & 22 & 23.3 & 26 & 27.2 \\
\hline & Kailla beel & 28 & 27.7 & 23 & 21.5 & 27 & 28.4 \\
\hline \multirow[t]{2}{*}{$\mathrm{pH}$} & Jailka beel & 6.8 & 7.2 & 7.0 & 6.8 & 7.3 & 7.5 \\
\hline & Kailla beel & 6.9 & 6.8 & 6.6 & 6.9 & 6.7 & 7.5 \\
\hline \multirow[t]{2}{*}{ Dissolved oxygen (mg/l) } & Jailka beel & 5.0 & 4.3 & 4.0 & 4.2 & 4.5 & 4.7 \\
\hline & Kailla beel & 4.3 & 4.5 & 4.0 & 4.0 & 4.0 & 4.5 \\
\hline \multirow[t]{2}{*}{ Ammonia (mg/l) } & Jailka beel & 0.0 & 0.03 & 0.05 & 0.1 & 0.10 & 0.21 \\
\hline & Kailla beel & 0.1 & 0.0 & 0.0 & 0.0 & 0.10 & 0.20 \\
\hline \multirow[t]{2}{*}{ Total hardness (mg/l) } & Jailka beel & 80 & 0.0 & 50 & 60 & 75 & 100 \\
\hline & Kailla beel & 70 & 80 & 70 & 50 & 70 & 110 \\
\hline \multirow[t]{2}{*}{ Total alkalinity (mg/l) } & Jailka beel & 90 & 70 & 60 & 55 & 70 & 120 \\
\hline & Kailla beel & 80 & 60 & 50 & 60 & 80 & 90 \\
\hline \multirow{2}{*}{ Nitrite (mg/l) } & Jailka beel & 0.1 & 0.1 & 0.1 & 0.05 & 0.05 & 0.1 \\
\hline & Kailla beel & 0.1 & 0.1 & 0.1 & 0.0 & 0.07 & 0.1 \\
\hline
\end{tabular}

Hossain (2000) and Kohinoor (2000) recorded dissolved oxygen values of fish ponds ranging from 3.8 to 6.9 $\mathrm{mg} / \mathrm{l}$ and 2.04 to $7.5 \mathrm{mg} / \mathrm{l}$ respectively at Mymensingh region. In the present study, the values of ammonia were very much nearer that ranged from 0.0 to $0.21 \mathrm{mg} / \mathrm{l}$ in both the beels. Wahab et al. (1995) reported that ammonia content of 0.19 to $0.28 \mathrm{mg} / \mathrm{l}$ in their experimental areas. Akter et al. (2009) observed increased level of ammonia during winter period.

\subsection{Clinical observations}

Fish had almost normal appearance except some fin erosions were recorded in October and November. In the month of January, large deep whitish ulcers reached up to deep ulcers, red spots and patches in lateral and ventral regions (Figures 1 and 2). However, in February and March, abrasions recovered to almost normal appearance in both beels (Figure3).
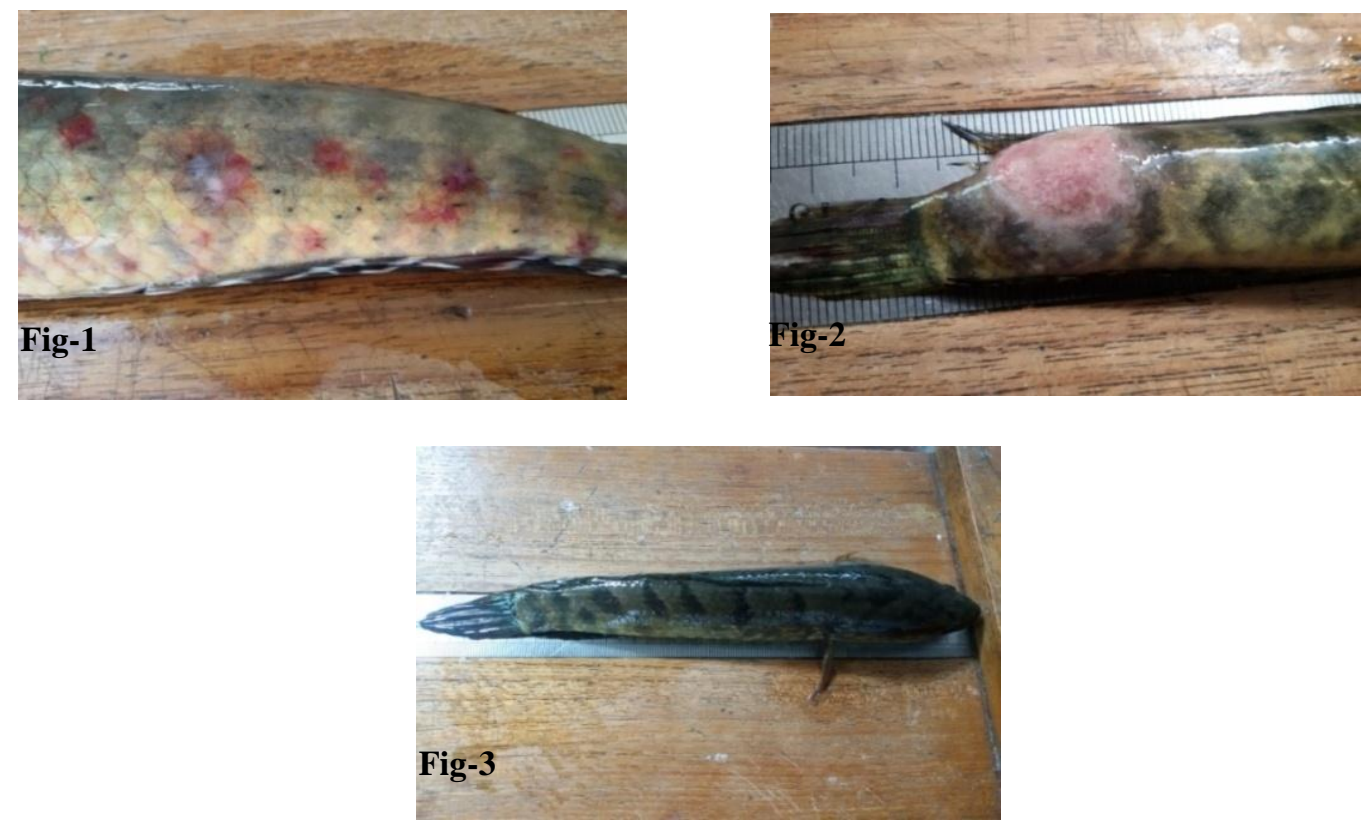

Figure 1. $C$. punctatus in December from Kailla beel having numerous red spots and patches in lateral and ventral regions.

Figure 2. $C$. punctatus in January from Jailka beel with large deep whitish ulcer reached up to deep ulcers.

Figure 3. Nearly recovered to normal $C$. punctatus in March from Kailla beel. 
Table 2. Clinical observation of investigated fish of the two beels in different months.

\begin{tabular}{lllllll}
\hline Month & October & November & December & January & February & March \\
\hline $\begin{array}{c}\text { Jailka } \\
\text { beel } \\
\text { Kailla beel }\end{array}$ & Weak body & Fin erosion & $\begin{array}{l}\text { Whitish deep ulcer, weak } \\
\text { body }\end{array}$ & $\begin{array}{l}\text { Large ulcer, weak } \\
\text { body }\end{array}$ & AN & HA \\
\hline
\end{tabular}

$\mathrm{AN}=\mathrm{Almost}$ normal, WB=Weak body, $\mathrm{RS}=$ Red spot, HA= Healthy appearance.

Clinically, C. punctatus had almost normal except some fin erosions were recorded in November from Jailka beel. In January, large deep whitish ulcer reached up to deep ulcers was observed from Jailka beel (Table 2). From research findings of Haque et al. (1999) it was observed that, large deep and whitish ulcer in the lateral and region, part of fins, scales and muscle were clinical sings of EUS affected fishes. Parveen (2001) observed that, three small indigenous fishes like P. ticto, N. nandus and C. punctatus from four beels of Mymensingh district, and observed that fishes were severely affected during the months of December and January. Ahmed $e t$ al.(2012) reported that the Tilapia was more affected from December and January and different clinical symptoms like rough skin, scale loss, red spots and dermal lesions were noticed. C. punctatus had numerous red spots and patches in lateral and ventral regions throughout the body in December from Kailla beel. Ahmed et al. (2007) also observed that scale loss, ill body and rough skin, minor ulcer and small red spots in December and January. Clinical symptoms such as abrasions were recovered to normal appearance in March from Kailla beel. From the result of the present experiment it was observed that severities of clinical signs were increased in December and January in both the beels (Table 2). In present study, C. punctatus was more affected from Jailka beel than Kailla beel.

\subsection{Histopathological observations of the organs of investigated fish}

During the month of November, gill was almost normal except some secondary gill lamellae were missing. However, in January, primary gill lamellae were separated, secondary gill lamellae were lost, necrotic and hypertrophied. Gill lamellae were almost recovered except some secondary gill lamellae yet to be recovered in the month of February in both beels. In November, dermis were separated from muscle; vacuums were seen in muscle. Whereas, in the month of January, muscle had fungal granuloma, vacuums and necrosis. However, skin was recovered but muscle had still necrosis and vacuums in February. In the month of November, liver was almost normal except vacuums. Necrosis, hemorrhage and vacuums were seen in January. However, in February, the structure of liver was almost recovered except vacuums. In the month of October, kidney was seen with normal structure. In January, large vacuum and necrosis was recorded. During the month of February, normal structure of kidney was seen. External organs likes gill and skin and muscle are severe affected than internal organs likes liver and kidney. Several research works had been conducted in Bangladesh on disease investigation of small indigenous fish with clinical and histopathological methods as disease diagnosis tools. In the present study, small indigenous fish like taki (C. punctatus) was considered to monitor health and disease in the Jailka beel from Sherpur and Kailla beel from Mymensingh areas of Bangladesh. The results of this study are discussed below and compared with the results of other works in the relevant field.

Histopathologically, it was observed in present study that all organs of $C$. punctatus likes gill, skin and muscle, liver and kidney was almost normal in October, mild affected in November and severely affected in December and January and infected organs were healed up to almost normal structure in February and March from both beel. Ahmed et al. (2012) mentioned that less affected gill were found in Oreochromis niloticus in November. Konika (2011) observed less pathological changes such as hypertrophy, clubbing and few lamellar missing in Cirrhinus cirrhosus during November. In January, primary gill lamellae were separated; secondary gill lamellae were lost, necrotic and hypertrophied in C. punctatus of Jailka beel. Whereas, fish organs of Kailla beel, primary and secondary gill lamellae were almost lost, hypertrophied and hyperplasic in December. According to Ahmed et al. (2012) O. niloticus gill had hypertrophy, hyperplasia, clubbing, hemorrhage in primary gill lamellae and secondary gill lamellae were lost during December and January. According to Ahmed et al. (2009) gills were healed up to almost normal structure in February and March. Konika (2011) observed less pathological changes such as loss of epidermis, necrotic muscles and vacuums were seen in $C$. cirrhosus during November. Muscle had fungal granuloma, vaccums and necrosis in muscle of $C$. punctatus from Jailka beel in January. However, in Kailla beel, muscle had fungal granuloma, vacuums, necrosis and hemorrhage in December. Ahmed et al. (2010) also observed that epidermis and dermis were partly lost, necrosis, hemorrhage, fungal hyphae were seen in A.testudineus during the months of December and January. Hossain et al. (2009) reported that severe necrosis 
of hepatocytes, pyknosis, vacuoles, fat droplets and hemorrhage were observed in small indigenous species during December and January. Mondal (2012) reported that the structure of liver in A. testudineus, B. gonionotus and $P$. hypophthalmus had severe necrosis, vacuums and hemorrhages in investigating farms during December and January. According to Mondal (2012), during February and March, almost normal liver except few vacuums were seen in A. testudineus, B. gonionotus and $P$. hypophthalmus from investigated farms. Mondal (2012) reported that Anabas testudineus had tubular degeneration, necrosis, hemorrhage, pyknosis and vacuums from fishes of Swopon Fish Farm and in Fishes of BAU Fish Farm, had tubular degeneration, necrosis, hemorrhage and vacuums in December and January. Ahmed et al. (2009) also observed necrosis, vacuums, hemorrhage and blood cells in kidney tubule of Anabas testudineus during the months of December and January. Ahmed et al. (2012) observed that in February and March, kidney pathology was recovered to almost normal structure except vacuums. Khatun (2011) mentioned that kidney pathology were recovered to almost normal structure except some vacuums in March. Organ wise, internal organs such as liver and kidney were less affected than external organs like skin, muscles and gill in the present study.
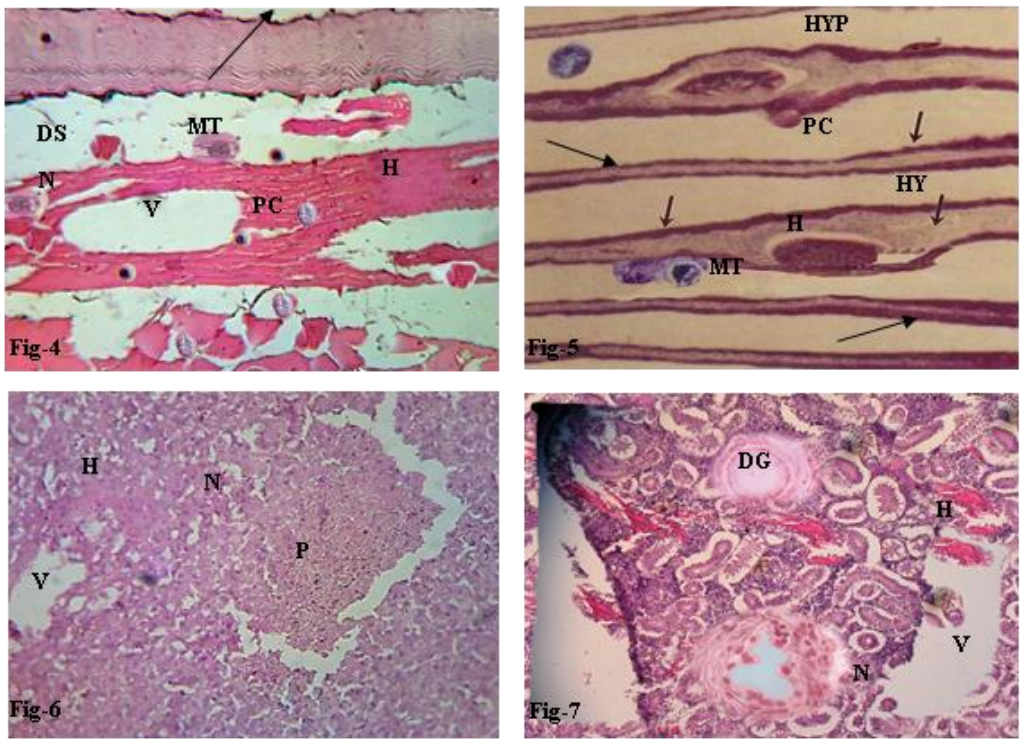

Figure 4. Photomicrograph of skin and muscle of $C$. punctatus in December from Jailka beel Having epidermal missing (arrow), dermis sloughed off (DS) from muscle, necrosis (N), vacuums (V) and haemorrhage (H) with monogenetic trematode (MT) and protozoan cysts (PC) (H \& E x 130).

Figure 5. Cross section of gill of $C$. punctatus in January from Kailla beel showing monogenetic trematodes (MT) and protozoan cyst (PC). Loss of secondary gill lamellae (arrow) along with hypertrophy (HY), hemorrhage (H) and hyperplasia (HYP) (H \& E x 130).

Figure 6. Section severely affected of gill of $C$. punctatus in January from Jailka beel having necrotic $(\mathrm{N})$ hepatic, hemorrhage (H), pyknosis (P) and vacuums (V) (H \& E x 130).

Figure 7. Section of gill of $C$. punctatus in December from Kailla beel having degenerated glomerulus (DG), vacuum (V), haemorrhage (H) and necrosis (N) (H \& E x 130).

\section{Conclusions}

The water quality parameters were in suitable range throughout the study period except temperature and total hardness which were reduced in December and January. In December and January when water temperature was $21.5^{\circ} \mathrm{C}$ and $22^{\circ} \mathrm{C}$, diseases like EUS occurred with marked pathological changes in various organs. Fish samples were collected at monthly intervals. In present study, sample fish was almost normal during the month of October. The fish had numerous clinical sings seen in lateral and ventral regions in December from Kailla beel. Whereas, large deep whitish ulcers reached up to deep ulcers was found during January in fish of Jailka beel. During histopathological study, normal structure was found in October from both the beels. Mild pathological changes were seen in both the beels in November. However, pathological changes were increased in the fish in December and January. The present study showed the fish species of Jailka beel were more affected than Kailla beel. Under Pathological observation, fish was affected by epizootic ulcerative syndrome (EUS). The skin and muscle in fish was more affected due to epizootic ulcerative syndrome (EUS). Thus if proper preventive and control measures can not be taken, the open water fishery will face tremendous threat in 
the near future. Therefore, proper preventive measures would need to be taken through integration with other agricultural sectors in order to save this vast fishery resource.

\section{Conflict of interest}

None to declare

\section{References}

Ahmed GU, T Khatun, MB Hossain and M Samsuddin, 2012. Health condition of a farmed tilapia (oreochromis niloticus) in earthen ponds, Northern Bangladesh. Bangladesh J. Fish., 12: 287-293.

Ahmed F 2010. Histopathological studies of carps, catfishes and a perch experimentally infected with Aeromonas Hydrophila bacteria, MS Thesis, Department of Aquaculture Bangladesh Agricultural University, Mymensingh. 63 pp.

Ahmed GU, MM Hossain and MM Hassan, 2009. Seasonal variation of disease and pathology of a perch, Nandus nandus from Oxbow-lake fisheries of Bangladesh. Ecofri. Agricul. J., 26: 761-767.

Ahmed GU, M Dhar, MNA Khan and D Choi, 2007. Investigation of diseases of Thai Koi, Anabas testadineus (Bloch) from Farming Conditions in winter. J. Life. Sci., 17: 1309-1314.

Akter MN, GU Ahmed and MS Hossain, 2009. Seasonal variation of gill pathology of a climbing perch in lake fisheries of Bangladesh. Int. J. Ani. Fish. Sci., 2: 208-213.

Alim MA, 2005. Developing a polyculture technique for farmer's consumption and cash crop, PhD Dissertation, Department of Fisheries Management, Bangladesh Agricultural University, Mymensingh. 271 pp.

Barua G, ANH Banu and MH Khan, 1989-91. An investigation into the prevalence of fish disease in Bangladesh during 1988-1989. Bangladesh J. Aqua., 11: 75 -79.

Chowdhury MBR, 1993. Research priorities for microbial fish disease and its control in Bangladesh. In: Proceeding of the Workshop on Research Priorities of Bangladesh for fish health, disease prevention and pathology. May 17, edited by Alam Tollervey. 8-11 pp.

Felts RA, F Rajts and M Akhteruzzaman, 1996. Small indigenous fish species culture in Bangladesh (Technical Brief), IF ADEP sub-project- 2. Development of Inland Fisheries. 41 pp.

Haque MA, MS Hossain, GU Ahmed and Z Tazri, 2009. Clinical and pathological investigation disease in some small indigenous species (SIS) from fish markets of Mymensingh. Int. J. Biores., 7: 1-6.

Hossain MY, 2000. Effects of 150 prosperous organic and inorganic fertilizers on water quality parameters and biological production, MS Thesis, Department of Fisheries Management, Bangladesh Agricultural University, Mymensingh. 47 pp.

Hossain MA and S Afroze, 1991. Small fish as a resource in rural Bangladesh. Fishbyte, 9: 16 - 18.

Hossian MS and MA Mazid, 1995. A manual on development of floodplain fisheries. Fisheries Research Institute, Mymensingh. p. 2 (In Bengali).

Khatun T, 2011. Study of health condition of farmed tilapia (Oreochromis niloticus), from two upazilas of Mtmensingh region, MS Thesis, Department of Aquaculture, Bangladesh Agricultural University, Mymensingh. 58 pp.

Kohinoor AHM, 2000. Development of culture technology of three small indigenous fish mola (Amblypharyngodon mola), punti (Puntinus sophere) and chela (Chela cachius) with notes on some aspects of their biology. A PhD dissertation, Department of Fisheries Management, Bangladesh Agricultural University, Mynensingh. 311 pp.

Konica MK, 2011. Investigation on culture and health status of mrigal Cirrhinus cirrhosus from the farming system of Mymensingh region, MS Thesis, Department of Aquaculture, Bangladesh Agricultural University, Mymensingh. $62 \mathrm{pp}$.

Mondal A, 2012. Investigation on the health status of some exotic fishes from farming condition of Mymensingh area, MS thesis, Bangladesh Agricultural University, Mymensingh. $52 \mathrm{pp}$.

Parveen R, 2001. Disease investigation of three small indigenous fishes from beel of Mymensingh, MS Thesis, Department of Aquaculture, Bangladesh Agricultural University, Mymensingh. 49 pp.

Rahman MM and MBR Chowdhury, 1996. Isolation of bacterial pathogen causing an ulcer disease in farmed carp fishes of Mymensingh. Bangladesh J. Fish., 19:103-110.

Rahman AKA, 1989. Fresh water fishes of Bangladesh, Zoological Society of Bangladesh, Dhaka. 364 pp.

Subasinghe RP, 1995. Note on Fish Disease Diagnosis and Health Management Training Workshop held from 22nd to 25th February, 1995. FRI, Mymensingh. 3-21 pp.

Swingle HS, 1967. Standardization of chemical analysis for waters and pond muds. FAO Fish Reproduction, 4: 397-421. 
Thilsted SH, N Roos and N Hassan, 1997. The role of small indigenous fish species in food and nutrition security in Bangladesh, NAGA News letter, July December. 13 pp.

Tripathi SD, 1997. The role of fisheries and Aquaculture in improving the food and nutrition security in Bangladesh. Paper presented at the Training workshop in food nutrition security in Bangladesh. Organized by BRRI and ENRECA project, 12 March 1997, Bangladesh.

Wahab MA, ZF Ahmed, MA Islam and SM Rahmatullah, 1995. Effect of introduction of common carp, Cyprinus carpio (L), on the pond ecology and growth of fish polyculture. J. Aqua. Res., 26: 619-628. 